\title{
Water flow enhances ammonium and nitrate uptake in a seagrass community
}

\author{
Christopher D. Cornelisen ${ }^{1,2, *}$, Florence I. M. Thomas ${ }^{1}$ \\ ${ }^{1}$ Department of Biology, University of South Florida, Tampa, Florida 33620, USA \\ ${ }^{2}$ Present address: Cawthron Institute, 98 Halifax St East, Nelson, New Zealand
}

ABSTRACT: The impact of hydrodynamic regime on rates of nutrient uptake for a seagrass community and for individual components of the community (Thalassia testudinum, epiphytes, phytoplankton, microphytobenthos) was quantified through the deployment of a field flume and application of ${ }^{15} \mathrm{~N}$-labeled ammonium and nitrate tracers. Ammonium uptake rates for the community and for seagrass leaves and epiphytes were enhanced with increased bulk velocity (uptake rate $\propto U_{\mathrm{b}}{ }^{0.57}$ to 0.70 ) and Reynolds shear stress at the top of the canopy (uptake rate $\propto \tau_{\mathrm{R}}{ }^{0.32}$ to $\left.{ }^{0.40}\right)_{\text {; }}$ thus, relationships expected for masstransfer limitation apply for the entire assemblage and individual components that form the canopy. Nitrate uptake rates for the community and for epiphytes $<35 \mu \mathrm{m}$ were also enhanced with increased bulk velocity (uptake rate $\propto U_{\mathrm{b}}{ }^{0.40}$ to 0.67 ) and Reynolds shear stress (uptake rate $\propto \tau_{R}^{0.19 \text { to } 0.32}$ ), but less so than ammonium uptake rates. For all components, uptake rates for $\mathrm{NO}_{3}{ }^{-}$were lower than those for $\mathrm{NH}_{4}{ }^{+}$, suggesting that nitrate uptake was affected by a biological factor (e.g. availability of nitrate reductase). Epiphytes and phytoplankton each accounted for 40 to $45 \%$ of the total ammonium and nitrate recovered; however, these components contributed the least to total particulate nitrogen in the community. Uptake by seagrass leaves and sediments containing microphytobenthos each represented $<5 \%$ of the ammonium and $<10 \%$ of the nitrate recovered, but contained the majority of particulate nitrogen. Our results emphasize the importance of epiphytes and phytoplankton in nitrogen uptake from the water column over the short term, and reaffirm that seagrasses and sediments play an integral role in the long-term retention of nitrogen within the canopy.

KEY WORDS: Ammonium uptake - Nitrate uptake · Seagrass $\cdot{ }^{15} \mathrm{~N} \cdot$ Isotope label $\cdot$ Thalassia testudinum Epiphytes $\cdot$ Water flow

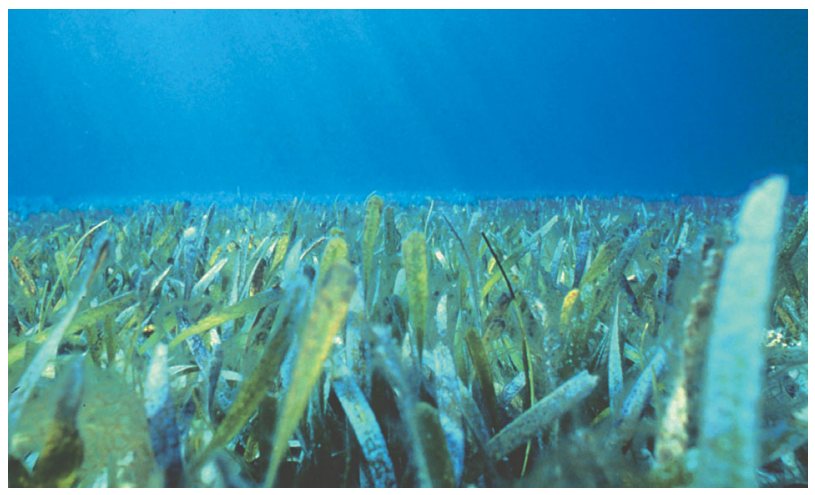

Thalassia testudinum meadows exhibit an exceptional ability to assimilate water-column nutrients that is attributed not only to the seagrass plants, but an abundance of epiphytes, benthic microalgae and phytoplankton

Photo: Paige Gill, FKNMS

\section{INTRODUCTION}

Seagrasses are found in shallow estuarine and nearshore waters that are physically dynamic and experience rapid fluctuations in salinity, turbidity and water flow. The canopies formed by seagrass plants serve many important ecological functions in the marine environment, including attenuation of water flow, which enhances the trapping and settlement of particles (Fonseca \& Kenworthy 1987, Koch 1999), and the transport and recruitment of larvae (Eckman 1987). Seagrass communities efficiently remove nutrients from the water column (Thomas et al. 2000), and uptake and retention of nutrients by seagrass beds maintains water quality for neighboring benthic communities, such as coral reefs (Short \& Short 1984). 
Seagrass canopies give rise to a diverse and highly productive community that includes seagrass plants, epiphytes, microphytobenthos and phytoplankton. Enrichment of water-column nutrients promotes increased biomass of epiphytes and phytoplankton, subsequent light attenuation, and decreased seagrass productivity (Short et al. 1995); the productivity of epiphytes can then equal and even exceed that of the seagrass leaves (Moncreiff et al. 1992).

Previous studies have investigated nutrient uptake by epiphytes (Cornelisen \& Thomas 2002) and interactions between epiphytes and seagrasses (McRoy \& Goering 1974). In addition, there have been studies on the uptake kinetics of estuarine phytoplankton (Wheeler et al. 1982) and microphytobenthos that inhabit estuarine sediments (Hansen et al. 2000). Nutrient uptake by seagrass plants and the role of leaves and roots in nutrient acquisition is also well documented (Iizumi \& Hattori 1982, Short \& McRoy 1984, Lee \& Dunton 1999). More recent studies in natural seagrass beds have demonstrated that hydrodynamic regime influences the rate at which the community as a whole (Thomas et al. 2000) and specific components such as epiphytes (Cornelisen \& Thomas 2002) and Thalassia testudinum leaves (Cornelisen \& Thomas 2004) remove dissolved inorganic nitrogen (DIN) from the water column. These studies have emphasized the importance of water motion on nutrient uptake in seagrass canopies and have begun to address ecological questions. For instance, does hydrodynamic regime have a similar impact on DIN uptake by the community as a whole, as it does on individual components situated within the community? Furthermore, what is the fate of water-column nutrients within the community, and in turn the contribution of different components to total uptake from the water column?

Previous studies have observed consistent relationships between measured hydrodynamic parameters (e.g. bulk velocity) and rates of nutrient uptake for benthic communities, such as coral reef flats (see Hearn et al. 2001, Baird et al. 2004) and seagrass beds (Thomas et al. 2000). For example, Hearn et al. (2001) demonstrated that uptake by coral assemblages is proportional to both bulk velocity (uptake rate $\propto U_{\mathrm{b}}{ }^{0.75}$ ) and bottom shear stress (uptake rate $\propto \tau^{0.40}$ ). We might then expect that uptake rates for organisms that comprise the canopies of these communities are similarly dependent on water flow characteristics (Cornelisen \& Thomas 2004). However, biological factors such as the availability of uptake sites or enzymes can also limit rates of nutrient uptake for specific components within the community. Furthermore, water flow may have little impact on uptake by organisms suspended in the water column (plankton) or those situated in attenu- ated flow at the base of the canopy (microphytobenthos). Both physical and biological factors can therefore influence the proportion of nutrients assimilated by community components.

Previous studies on epiphyte and phytoplankton productivity under nutrient enrichment suggest that these components are the primary sinks for water-column nutrients (Short et al. 1995), perhaps due to their proximity to these nutrients. While this may apply over the short term, the large amount of particulate nitrogen retained in seagrass leaves and sediments compared to epiphytes and phytoplankton suggests that seagrasses play an important role in trapping suspended particulate organic matter (POM), and in turn assimilating and retaining nitrogen derived from $\mathrm{POM}$ over the long term (Stapel et al. 2001). This is further supported by a recent study that used ${ }^{15} \mathrm{~N}$-labeled phytodetritus to identify POM in the sediments as an important nitrogen source for seagrass plants (Evrard et al. 2005).

The objectives of our study were to (1) assess the influence of hydrodynamic regime on the short-term uptake of ammonium and nitrate by a seagrass community as a whole and by individual components of the community, including Thalassia testudinum leaves, epiphytes, microphytobenthos and phytoplankton, and (2) quantify the relative contributions of these components to total DIN uptake by the community. In order to isolate uptake by individual components, sections of natural $T$. testudinum beds were enclosed within a field flume and exposed to ${ }^{15} \mathrm{~N}$-labeled DIN. Two series of field experiments were conducted: one using ammonium and one using nitrate as the labeled DIN source. This allowed for the comparison of uptake rates for 2 different forms of nitrogen that vary in physiological requirements for uptake (Touchette \& Burkholder 2000). Uptake rates were quantified over a range of water velocities ( 0.02 to $0.18 \mathrm{~m} \mathrm{~s}^{-1}$ ), and velocity profiles collected with an acoustic Doppler velocimeter were used to measure bulk velocity and shear stress at the top of the canopy. The dependence of community and individual component uptake rates on these hydrodynamic parameters was then evaluated and compared. The contribution of uptake by each component to the total DIN recovered was also estimated and evaluated in light of each component's contribution to the total particulate nitrogen pool.

\section{MATERIALS AND METHODS}

Flume deployment. Flume experiments were carried out in beds of Thalassia testudinum located at the entrance to Tampa Bay and adjacent to Fort Desoto County Park, Florida, USA (see Cornelisen \& Thomas 
2004 for site details). Uptake rates were measured between 7 and 14 June 2001 for ammonium and between 17 and 22 June 2001 for nitrate. The field flume enclosed a $3.7 \mathrm{~m}^{2}$ area of the seagrass bed and allowed us to impose controlled unidirectional flow (via a trolling motor) over the benthos, and to measure nutrient uptake by the community and associated organisms enclosed within the flume (see Thomas et al. 2000, Cornelisen \& Thomas 2004 for description). For each estimated uptake rate, the flume was moved to a new location in the seagrass bed and a 45 to $60 \mathrm{~min}$ experiment was conducted at a velocity within a predetermined range observed in the field (0.02 to $\left.0.18 \mathrm{~m} \mathrm{~s}^{-1}\right)$. A total of 9 and 7 flume experiments were conducted at velocities within this range for ammonium and nitrate uptake, respectively.

Hydrodynamic regime. A vertical profile of velocity was collected during each flume experiment and was used to estimate hydrodynamic parameters, including bulk velocity $\left(U_{\mathrm{b}}\right)$ and Reynolds shear stress $\left(\tau_{\mathrm{R}}\right)$. Velocity data were collected using an acoustic Doppler velocimeter (10 Hz Field ADV, YSI/Sontek) that measures velocity in 3 dimensions: longitudinal $(U)$, transverse $(V)$, and vertical $(W)$. To create each vertical profile, data were recorded at $5 \mathrm{~Hz}$ at 4 to 6 heights within the canopy and at least 5 heights between the canopy and the surface of the water. Due to the short duration of experiments, the length of the sampling period was limited to $1 \mathrm{~min}$ to maximize the number of heights for data collection within each profile. We recognize that short sampling periods do not provide as much information about turbulent structure as long sampling periods; however, both long ( 10 $\mathrm{min})$ and short (1 min) sampling periods taken during some flume experiments provided similar estimates of shear based on the velocity gradient.

Bulk velocity $\left(U_{\mathrm{b}}\right)$ was estimated as the depthaveraged velocity in the dominant direction of flow $(\bar{U})$. Reynolds shear stress $\left(\tau_{R}\right)$ at a given height was calculated as Reynolds stress $\left(-\overline{U^{\prime} W^{\prime}}\right) \times$ seawater density. $U^{\prime}$ and $W^{\prime}$ are the fluctuations around the mean longitudinal and vertical velocities, respectively. Bottom shear stress and turbulent energy dissipation based on the logarithmic portion of the velocity profile also correlate with nutrient uptake rates (see Cornelisen \& Thomas 2004). However, previous studies on fluid flow through vegetation canopies suggest that the distribution and generation of turbulence in and above the canopy is more indicative of a mixing layer than perturbed boundary layer flow (Raupach et al. 1996, Ghisalberti \& Nepf 2002). Therefore, $U_{\mathrm{b}}$ and $\tau_{\mathrm{R}}$ at the top of the canopy were chosen as the most appropriate parameters to correlate with nutrient uptake by the community as a whole and by individual components.
Uptake rates. For the determination of nitrogen uptake rates, the flume was sealed from the surrounding water and a spike of DIN, either ${ }^{15} \mathrm{NH}_{4} \mathrm{Cl}$ or $\mathrm{Na}^{15} \mathrm{NO}_{3}{ }^{-}\left(98\right.$ atom $\left.\%{ }^{15} \mathrm{~N}\right)$, was added $\left(20 \mathrm{mmol} \mathrm{l}^{-1}\right)$ just upstream of the motor box in order to obtain a well mixed water-column concentration. The concentration immediately after the addition of the spike ranged from 5 to $7 \mu_{\mathrm{mol} \mathrm{l}}^{-1}$ and 4 to $5 \mu \mathrm{mol} \mathrm{l}^{-1}$ for the ammonium and nitrate experiments, respectively. Uptake rates for the community as a whole were based on the decline in water-column DIN concentration (either as $\mathrm{NH}_{4}{ }^{+}$or $\mathrm{NO}_{3}{ }^{-}$) over the course of an experiment (see Thomas et al. 2000). A first-order rate constant ( $k$ ) was estimated as the slope of the natural log concentration $(C)$ versus time $(t)$, where $C=-k \mathrm{~d} C / \mathrm{d} t$. Each $k$ value was based on 6 to 7 water samples collected over the course of an experiment. Values of $k$ were normalized for water volume in the flume $(\mathrm{Vol})$ and planar surface area of the benthos enclosed by the flume $(A)$ to estimate an uptake rate constant $(S)$, where $S=k \times$ Vol/A. Values of $S\left(\mathrm{~m} \mathrm{~s}^{-1}\right)$ can be multiplied by concentration (e.g. moles $\mathrm{NH}_{4}{ }^{+} \mathrm{m}^{-3}$ ) to yield a specific uptake rate (in moles $\mathrm{NH}_{4}^{+} \mathrm{m}^{-2} \mathrm{~s}^{-1}$ ). An estimate of the total $\mathrm{NH}_{4}{ }^{+}$or $\mathrm{NO}_{3}{ }^{-}$removed from the water column over time by the whole community was calculated from the regression of concentration versus time for each experiment.

Rates of $\mathrm{NH}_{4}{ }^{+}$or $\mathrm{NO}_{3}{ }^{-}$uptake were determined for seagrass leaves, attached epiphytes, microphytobenthos at the sediment-water interface, and phytoplankton. Samples of each of these components were collected prior to experiments for determination of ambient isotope ratios and at the end of each experiment to determine uptake rates based on ${ }^{15} \mathrm{~N}$ accumulation over time. Immediately following each experiment, approximately 10 whole seagrass leaves were removed randomly from within the flume. Epiphytes, including diatoms, blue-green algae, crustose corallines (e.g. Fosliella sp.), encrusting brown algae (e.g. Myrionema sp.) and branching red algae (e.g. Ceramium sp.), were separated from the leaves by gently scraping the leaves with the edge of a microscope slide. The seagrass leaves cleaned of epiphytes were then rinsed and pooled to represent the seagrass sample. Senescent leaves were not retained for ${ }^{15} \mathrm{~N}$ analysis due to the difficulty in removing all epiphytes cleanly from the leaf surface.

Epiphyte material removed from leaves was pooled to represent the epiphyte sample. Half of the sample was used for isotope analysis and half for determination of chl a. Normalizing uptake rates to chl a corrects for the presence of heterotrophic organisms that do not actively remove DIN from the water column (Cornelisen \& Thomas 2002). Epiphytes for ${ }^{15} \mathrm{~N}$ analysis were rinsed with filtered seawater over a $35 \mu \mathrm{m}$ mesh 
stacked over a $0.7 \mu \mathrm{m}$ pre-weighed and combusted GF/F filter to partition the epiphytic material into 2 size classes ( $>35 \mu \mathrm{m}$ and 0.7 to $35 \mu \mathrm{m}$ ). No visual comparison of organisms within small and large size fractions of epiphytes was made; therefore, it is possible that the large size fraction included organisms $<35 \mu \mathrm{m}$. Following the filtered seawater rinse, epiphytes were briefly rinsed with deionized water to remove salt. A sample of seagrass leaves with epiphytes still attached were retained and were not separated or rinsed, to assess the potential loss of ${ }^{15} \mathrm{~N}$ during sample processing. The loss from sample processing was estimated from uptake rates based on epiphytes and seagrass leaves that were not processed and the combined values for epiphytes and seagrass leaves that were separated and rinsed. Rinsing of samples could potentially affect the amount of ${ }^{15} \mathrm{~N}$ retained due to loss of small cells though the filter, lysing of cells or perhaps rinsing away of ${ }^{15} \mathrm{~N}$ that was adsorbed to the surface of the sample but was not assimilated.

Surface sediments were collected to assess the effects of water velocity on DIN uptake by microphytobenthos. Samples of surface sediments were collected for 7 of the $9 \mathrm{NH}_{4}{ }^{+}$experiments and for all 7 of the $\mathrm{NO}_{3}{ }^{-}$ experiments. Surface sediment (0 to $1 \mathrm{~cm}$ ) was scraped with a flat spatula from several locations in the area enclosed by the flume into a Whirl-Pak ${ }^{\circledR}$ bag (Nasco). The sample was split, with half designated for isotope analysis and half for determination of chl $a$. There was no attempt to separate microalgae from the sediments. Therefore, the samples included a mixture of benthic microalgae (pennate diatoms), detrital organic matter and inorganic sediments.

Particulate organic nitrogen (PON) filtered from the water column was used as an estimate of phytoplankton. Immediately upon completion of each experiment, a sample of water was collected by filling a 11 bottle (Nalgene) at mid-water depth within the flume. The water was filtered at the site through a pre-weighed and combusted GF/F filter using a hand pump (Nalgene) and a 21 filter flask. Filters containing samples of PON and the small size fraction of epiphytes were wrapped in tinfoil and dried at $60^{\circ} \mathrm{C}$ for $24 \mathrm{~h}$. Samples of the seagrass leaves, large size fraction of epiphytes, and sediments designated for isotope analysis were dried at $60^{\circ} \mathrm{C}$ for $24 \mathrm{~h}$, homogenized with a mortar and pestle, and stored in individual glass vials until analyzed.

Chl a concentrations were determined for epiphyte and sediment samples. Three sub-samples $(\sim 0.5 \mathrm{~g}$ wet wt) from each sample were placed in individual $15 \mathrm{ml}$ glass test tubes with $10 \mathrm{ml}$ of $90 \%$ acetone. Tubes were then covered with parafilm and kept in the dark at $0^{\circ} \mathrm{C}$ for $24 \mathrm{~h}$ during the extraction. Following extraction, tubes were centrifuged and the extract decanted and read on a benchtop spectrophotometer at wavelengths 665 and $750 \mathrm{~nm}$ both before and after acidification with 2 drops of $5 \% \mathrm{HCl}$. Chl a (in $\mu \mathrm{g}$ ) was based on the equation:

Chl $a=26.7 \times\left[(665-750)-\left(665_{\text {acid }}-750_{\text {acid }}\right)\right] \times V o l$

where $\mathrm{Vol}$ is extract volume (Lorenzen 1967). These values were then divided by the dry weight of the sample and expressed as $\left(\mu \mathrm{g} \mathrm{chl} \mathrm{a)} \mathrm{(g} \mathrm{dry} \mathrm{wt)}{ }^{-1}\right.$. The mean value for 3 subsamples represented the estimate for a given sample.

All dried samples of seagrass, epiphytes, sediments, and PON were analyzed in an elemental analyzer coupled with an isotope ratio mass spectrometer (Europa Hydra IRMS coupled to a Carlo Erba NC $250)$ for determination of nitrogen content $(\% \mathrm{~N})$ and atom $\%{ }^{15} \mathrm{~N}$. Specific uptake rates (V) were calculated using the equation:

$$
\mathrm{V}=\left(\mathrm{d} a_{\mathrm{s}} / \mathrm{d} t\right) /\left(a_{\mathrm{w}}-a_{\mathrm{s}}\right)
$$

where $a_{\mathrm{s}}$ is the atom $\%{ }^{15} \mathrm{~N}$ in the component's tissue, $a_{\mathrm{W}}$ is the atom $\%{ }^{15} \mathrm{~N}$ of the enriched substrate, and $t$ is time (Dugdale \& Goering 1967). The units for V are (g $\mathrm{N}$ removed) (g N tissue) $)^{-1} \mathrm{~s}^{-1}$. The atom $\%{ }^{15} \mathrm{~N}$ of the enriched water $\left(a_{\mathrm{w}}\right)$ was based on the amount of 98 atom $\%{ }^{15} \mathrm{NH}_{4}{ }^{+}$or ${ }^{15} \mathrm{NO}_{3}{ }^{-}$added and background DIN concentrations (assumed to reflect ${ }^{15} \mathrm{~N}$ concentration of atmospheric $\mathrm{N} \sim 0.37$ atom $\%{ }^{15} \mathrm{~N}$ ). The numerator $\left(\mathrm{d} a_{\mathrm{s}} / \mathrm{d} t\right)$ was estimated as the difference in atom\% ${ }^{15} \mathrm{~N}$ between ambient samples and samples collected at the end of each experiment divided by the duration of the experiment. It is noted that the calculation of $\mathrm{V}$ assumes that the atom $\%{ }^{15} \mathrm{~N}$ of the source pool did not change during the course of the experiment. Dilution of ${ }^{15} \mathrm{~N}$ in the source pool resulting from inputs of nonlabeled $\mathrm{NH}_{4}{ }^{+}$(via regeneration, excretion) or $\mathrm{NO}_{3}{ }^{-}$(via nitrification) into the water column would result in underestimated uptake rates (Laws 1984); however, the short duration of experiments along with the high concentration and atom $\%{ }^{15} \mathrm{~N}$ of the spike likely minimized dilution.

$\mathrm{V}$ was normalized to the nitrogen concentration $(\% \mathrm{~N})$ of each component to calculate uptake rates $(\rho)$ in units ( $\mathrm{g} \mathrm{N}$ removed) ( $\mathrm{g}$ dry $\mathrm{wt})^{-1} \mathrm{~s}^{-1}$ (Dugdale \& Goering 1967). For epiphytes and sediments, uptake rates were normalized to $\mathrm{chl}$ a concentration in the sample to obtain an uptake rate that was representative of the autotrophic fraction: $\rho_{\mathrm{Chl}}=\rho \times \mathrm{chl} a^{-1}$ in units (g N removed) ( $\mu \mathrm{g} \mathrm{chl} a)^{-1} \mathrm{~s}^{-1}$; Dickson \& Wheeler (1995). For plankton, V was multiplied by $g \mathrm{PON}^{-1}$ to calculate $\rho$ in $\mathrm{g} \mathrm{N}^{-1} \mathrm{~s}^{-1}$.

The decline in ammonium or nitrate concentration in the water column was first-order. Therefore, it was assumed that the rate of ${ }^{15} \mathrm{~N}$ accumulation within organism tissues was also first-order. To compensate 
for changes in water-column concentration over time, $\rho$ was multiplied by a correction term $(\alpha)$. The correction term was calculated as:

$$
\alpha=k t /\left(1-\mathrm{e}^{-k t}\right)
$$

Values of $\alpha$ ranged from 1.13 to 1.29 and from 1.20 to 1.69 for $\mathrm{NO}_{3}{ }^{-}$and $\mathrm{NH}_{4}{ }^{+}$experiments, respectively. Uptake rates corrected for concentration change represent those for the water-column concentration at the start of experiments $\left(\sim 6 \mu \mathrm{M}\right.$ for $\mathrm{NH}_{4}{ }^{+}$experiments and $\sim 4 \mu \mathrm{M}$ for $\mathrm{NO}_{3}{ }^{-}$experiments) and were used to assess the effects of water flow on DIN uptake by the individual components.

Dependence of uptake rates, including $S$ and $\rho$, on hydrodynamic parameters $\left(U_{\mathrm{b}}\right.$ and $\left.\tau_{\mathrm{R}}\right)$ was evaluated using Model II regressions (geometric mean), since there was error in estimating both the dependent and independent variables (Sokal \& Rohlf 1995). Correlations between uptake rates and hydrodynamic parameters were also estimated using the product-moment correlation coefficient (r).

Component contributions to nitrogen uptake. Uptake rates $(\rho)$ for seagrass leaves, epiphytes, and sediments were multiplied by their total biomass in the flume $(\rho \times g$ dry wt) to estimate the total amount of $\mathrm{NH}_{4}{ }^{+}$or $\mathrm{NO}_{3}{ }^{-}$removed (in $\mathrm{g} \mathrm{N} \mathrm{s}^{-1}$ ) by each of these components over the course of each flume experiment. The total amount of ammonium or nitrate removed by PON in the water column was based on $\rho$, the concentration of PON ( $\mathrm{PON}^{-1}$ ), and the total volume of water in the flume. Uptake rates used for estimating the total amount removed by each component were the actual uptake rates, rather than those corrected for a decline in water column concentration as described above. Estimates of shoot density were obtained using quadrats $\left(0.01 \mathrm{~m}^{2}\right)$ placed within the area enclosed by the flume ( $\mathrm{n}=5$ for each experiment). Leaves and epiphytes within a quadrat were separated, dried $\left(60^{\circ} \mathrm{C}\right)$ and then weighed to determine biomass of these components in $\mathrm{g} \mathrm{m}^{-2}$. Biomass of surface sediments sampled between 0 and $1 \mathrm{~cm}$ was based on $\mathrm{cm}^{3}$ samples taken in the laboratory from those collected in the field during experiments. The estimate of total biomass of these sediments enclosed by the flume does not account for natural compaction in field conditions or the presence of the seagrass plants. Therefore, it is possible that sediment biomass is overestimated due to compaction following collection of samples or underestimated due to the area of the sediment surface that is occupied by short shoots of seagrass plants.

\section{RESULTS}

\section{Hydrodynamic regime}

Vertical profiles of velocity components $(U, V$, and $W)$ revealed that water flow in the flume was highly unidirectional and closely resembled profiles collected in natural tidal-driven flow over seagrass beds (Fig. 1A). Depthaveraged velocities $\left(U_{\mathrm{b}}\right)$ ranged between 0.03 and $0.17 \mathrm{~m}$ $\mathrm{s}^{-1}$ and between 0.03 and $0.18 \mathrm{~m} \mathrm{~s}^{-1}$ for the $\mathrm{NH}_{4}{ }^{+}$and $\mathrm{NO}_{3}^{-}$experiments, respectively. Reynolds stress $\left(-\overline{U^{\prime} W^{\prime}}\right)$ was highest at the top of the canopy (Fig. 1B) and estimates of shear stress $\left(\tau_{\mathrm{R}}\right)$ from these values ranged from 0.01 to $0.31 \mathrm{~N} \mathrm{~m}^{-2}$ for the $\mathrm{NH}_{4}{ }^{+}$experiments and from 0.02 to $0.20 \mathrm{~N} \mathrm{~m}^{-2}$ for the $\mathrm{NO}_{3}{ }^{-}$experiments. Estimates of $\tau_{\mathrm{R}}$ based on velocity data collected at heights ranging from 0.5 to $1 \mathrm{~cm}$ above the sediment surface (range, 0.002 to $0.008 \mathrm{~N} \mathrm{~m}^{2}$ ) were an order of magnitude lower than those at the top of the canopy and were not dependent on $U_{\mathrm{b}}$ (Fig. 2). In addition, mean
Fig. 1. (A) Vertical profiles of velocity in the main (longitudinal) flow $(U)$, transverse $(V)$, and vertical $(W)$ directions and (B) Reynolds stress collected during a flume experiment for measuring $\mathrm{NH}_{4}{ }^{+}$uptake rates (closed symbols) and in natural flow in a nearby Thalassia testudinum bed exposed to a similar range of velocity (open symbols). Profiles are shown for heights above the bottom $(Z)$ normalized to the deflected height of the canopy $\left(h_{\mathrm{d}}\right)$. The dashed line indicates the top of the canopy $\left(Z / h_{\mathrm{d}}=1\right)$
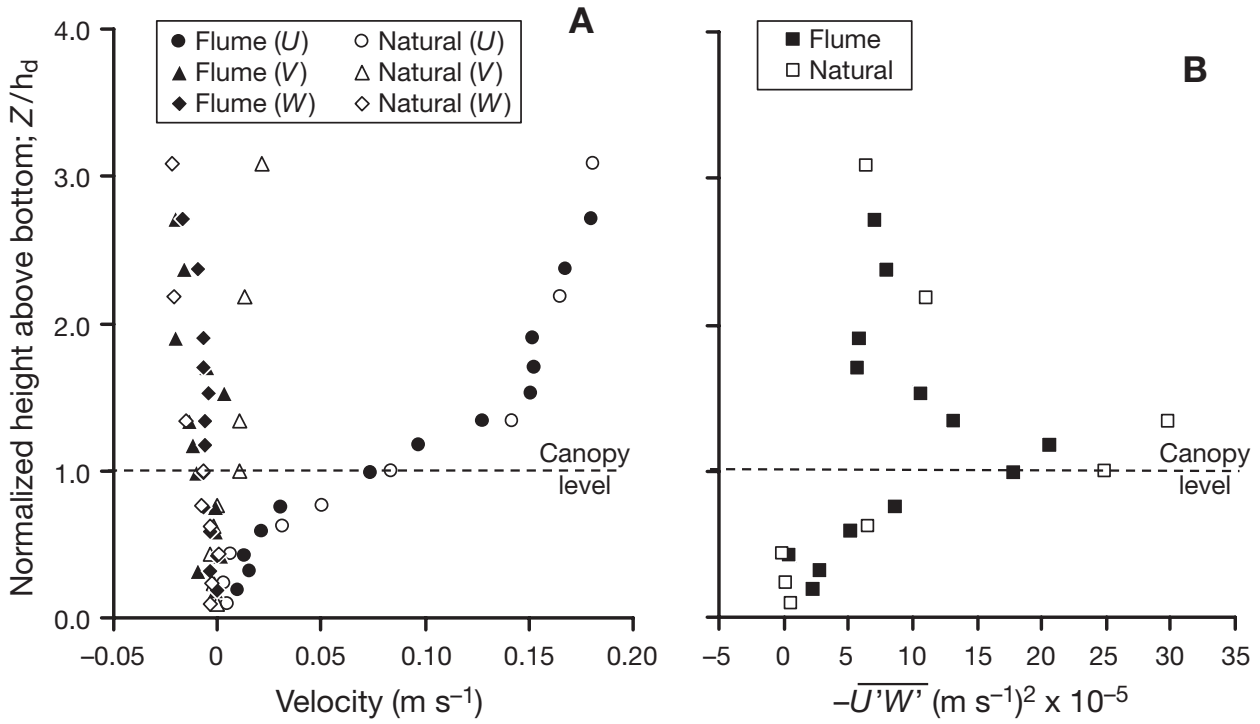
velocities at these heights fell below $0.001 \mathrm{~m} \mathrm{~s}^{-1}$ over the range of $U_{\mathrm{b}}$, indicating considerable flow attenuation at the base of the seagrass canopy.

\section{Uptake rates}

For all $9 \mathrm{NH}_{4}{ }^{+}$uptake experiments there was a significant first-order decline in ammonium concentration in the water column over time. Regressions used in determining $k$ for $\mathrm{NH}_{4}{ }^{+}$were all highly significant $(\mathrm{p}<0.001$; $\mathrm{r}^{2}=0.94$ to 0.99$)$. Uptake rate constants $(S)$ calculated from values of $k$ ranged from $7.5 \times 10^{-5}$ to $28.7 \times 10^{-5}$ $\mathrm{m} \mathrm{s}^{-1}$ and were significantly dependent on bulk velocity and shear stress at the top of the canopy (Tables $1 \& 2$, Fig. 3). There was a significant first-order decline in nitrate concentration in the water column over time for all $7 \mathrm{NO}_{3}{ }^{-}$uptake experiments. Regressions used in determining $k$ for $\mathrm{NO}_{3}^{-}$were all highly significant ( $\mathrm{p}<$ $0.001 ; \mathrm{r}^{2}=0.91$ to 0.99$)$. Uptake rate constants $(S)$ for nitrate were also dependent on bulk velocity and shear stress, however, less so than uptake rate constants for ammonium (Tables 1 \& 2, Fig. 3).

Labeled ammonium $\left({ }^{15} \mathrm{NH}_{4}^{+}\right)$was recovered in all sampled components including seagrass leaves, epiphytes, microphytobenthos, and phytoplankton (PON) for all $9 \mathrm{NH}_{4}{ }^{+}$uptake experiments. Labeled nitrate $\left({ }^{15} \mathrm{NO}_{3}{ }^{-}\right)$was also recovered in these components during each of the 7 flume experiments conducted for nitrate. Minimum and maximum rates of ammonium and nitrate uptake for each of the components are listed in Table 1. Rates of $\mathrm{NH}_{4}{ }^{+}$uptake for the leaves were statistically significantly dependent on bulk velocity and shear stress at the top of the canopy (Table 2, Fig. 4). One of the

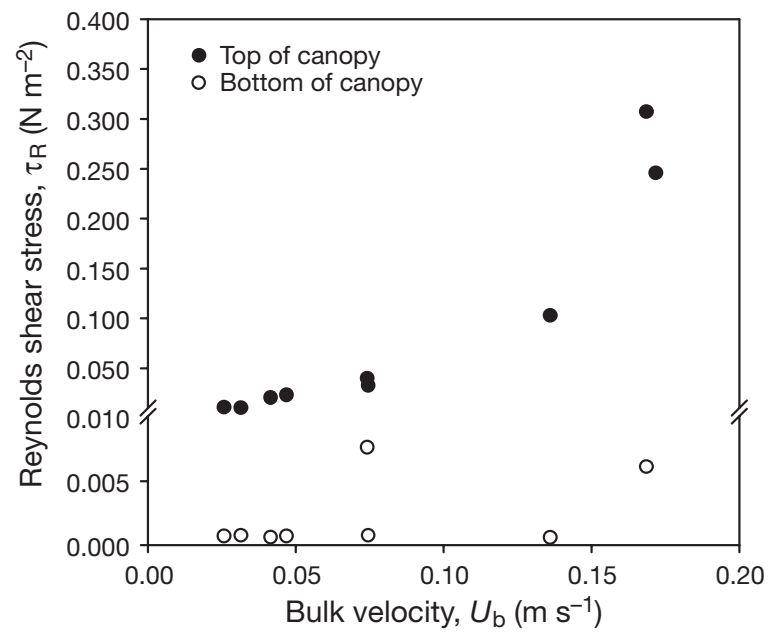

Fig. 2. Relationship between Reynolds shear stress $\left(\tau_{R}\right)$ and bulk velocity $\left(U_{\mathrm{b}}\right)$ for estimates of $\tau_{\mathrm{R}}$ at the top of the Thalassia testudinum canopy and at the base of the canopy $(0.5$ to $1 \mathrm{~cm}$ above the sediment surface). Estimates of $\tau_{\mathrm{R}}$ at the base of the canopy were an order of magnitude lower (range: 0.002 to 0.008 ) than at the top (note break in $y$-axis and change in scale).

Data shown are for ammonium uptake experiments

Table 1. Minimum and maximum uptake rates for components of a Thalassia testudinum community during field flume experiments. PON particulate organic nitrogen fraction suspended in the water column. Uptake rates for epiphytes and microphytobenthos include those normalized to chl a concentrations $\left(\rho_{\mathrm{Chl}}\right)$

\begin{tabular}{|c|c|c|c|}
\hline & \multicolumn{2}{|c|}{ Uptake rate } & \multirow[t]{2}{*}{ Units } \\
\hline & Ammonium & Nitrate & \\
\hline Community $(S)$ & $75-287$ & $78-127$ & $\mathrm{~m} \mathrm{~s}^{-1} \times 10^{-6}$ \\
\hline Seagrass leaves & $1.0-3.8$ & $0.46-0.84$ & g $N(\text { g dry wt })^{-1} \mathrm{~s}^{-1} \times 10^{-9}$ \\
\hline Epiphytes $>35 \mu \mathrm{m}$ & $\begin{array}{c}9.4-38.8 \\
12-37\end{array}$ & $\begin{array}{l}4.2-10.7 \\
3.7-8.5\end{array}$ & $\begin{array}{l}\text { g } N(\text { g dry wt })^{-1} \mathrm{~s}^{-1} \times 10^{-9} \\
\text { g } N\left(\mu \text { g chl a }^{-1} \mathrm{~s}^{-1} \times 10^{-12}\right.\end{array}$ \\
\hline Epiphytes <35 $\mu \mathrm{m}$ & $\begin{array}{c}8.2-39.8 \\
11-45\end{array}$ & $\begin{array}{l}7.8-18.7 \\
6-15\end{array}$ & $\begin{array}{l}\text { g } N(\text { g dry wt })^{-1} \mathrm{~s}^{-1} \times 10^{-9} \\
\text { g } N(\mu \mathrm{g} \text { chl a })^{-1} \mathrm{~s}^{-1} \times 10^{-12}\end{array}$ \\
\hline $\begin{array}{l}\text { Sediments } \\
\text { (Microphytobenthos) }\end{array}$ & $\begin{array}{l}2.0-5.9 \\
1.9-4.7\end{array}$ & $\begin{array}{r}0.5-2.4 \\
0.35-1.8\end{array}$ & $\begin{array}{l}\text { g } N(\text { g dry wt })^{-1} \mathrm{~s}^{-1} \times 10^{-12} \\
\text { g } N(\mu \mathrm{g} \text { chl a })^{-1} \mathrm{~s}^{-1} \times 10^{-12}\end{array}$ \\
\hline PON & $2.7-13.4$ & $1.0-4.1$ & $\mathrm{~g} \mathrm{~N}^{-1} \mathrm{~s}^{-1} \times 10^{-9}$ \\
\hline
\end{tabular}

Table 2. Regression results for uptake rates versus bulk velocity $\left(U_{\mathrm{b}}\right)$ and Reynolds shear stress at the top of the Thalassia testudinum canopy $\left(\tau_{R}\right)$. Statistics are shown for regressions that were significant $\left({ }^{*} p<0.05,{ }^{* *} p<0.01,{ }^{* * *} p<0.001\right)$. Regressions for ammonium and nitrate uptake by sediments (microphytobenthos) and nitrate uptake by seagrass leaves, the large fraction of epiphytes and PON versus hydrodynamic parameters were not significant ( $p>0.05)$

\begin{tabular}{|c|c|c|c|c|c|c|c|c|}
\hline & \multirow[b]{2}{*}{ Slope } & \multirow{2}{*}{${ }_{95 \% \mathrm{CI}} U_{\mathrm{b}}$} & \multirow[b]{2}{*}{$\mathrm{r}$} & \multirow[b]{2}{*}{$\mathrm{p}$} & \multirow[b]{2}{*}{ Slope } & \multirow{2}{*}{${ }_{95 \% \mathrm{CI}} \tau_{\mathrm{R}}$} & \multirow[b]{2}{*}{$\mathrm{r}$} & \multirow[b]{2}{*}{$\mathrm{p}$} \\
\hline & & & & & & & & \\
\hline \multicolumn{9}{|l|}{ Ammonium } \\
\hline Community $(S)$ & 0.68 & $0.49-0.88$ & 0.85 & ** & 0.39 & $0.21-0.57$ & 0.79 & * \\
\hline Seagrass leaves $(\rho)$ & 0.70 & $0.52-0.88$ & 0.90 & ** & 0.40 & $0.18-0.62$ & 0.85 & ** \\
\hline Epiphytes > $35 \mu \mathrm{m}\left(\rho_{\mathrm{Chl}}\right)$ & 0.57 & $0.38-0.76$ & 0.87 & ** & 0.32 & $0.13-0.51$ & 0.86 & ${ }^{* *}$ \\
\hline Epiphytes <35 $\mu \mathrm{m}\left(\rho_{\mathrm{Chl}}\right)$ & 0.63 & $0.41-0.85$ & 0.82 & ** & 0.36 & $0.14-0.57$ & 0.82 & ** \\
\hline PON $(\rho)$ & 0.79 & $0.54-1.03$ & 0.73 & * & 0.45 & $0.14-0.58$ & 0.73 & $* *$ \\
\hline \multicolumn{9}{|l|}{ Nitrate } \\
\hline Community $(S)$ & 0.40 & $0.23-0.57$ & 0.93 & ${ }^{* *}$ & 0.19 & $-0.03-0.41$ & 0.86 & ** \\
\hline Epiphytes <35 $\mu \mathrm{m}\left(\rho_{\mathrm{Chl}}\right)$ & 0.67 & $0.51-0.57$ & 0.92 & ** & 0.32 & $0.20-0.44$ & 0.96 & *** \\
\hline
\end{tabular}


uptake rates for leaves was omitted from the regression analyses due to its large influence on the dataset (e.g. DFFITS statistic $=2.8$ standard errors for $\rho$ versus $\left.U_{\mathrm{b}}\right)$. Rates of nitrate uptake for seagrass leaves were lower than those for ammonium (Table 1) and were not dependent on $U_{\mathrm{b}}$ or $\tau_{\mathrm{R}}$ (Fig. 4).

Ammonium uptake rates $(\rho)$ for both size fractions of epiphytes were approximately $90 \%$ higher than those for seagrass leaves (Table 1).Uptake rates normalized to chl a concentrations for both size fractions were statistically significantly dependent on bulk velocity and shear stress at the top of the canopy (Table 2, Fig. 4). Nitrate uptake rates for epiphytes were lower than those for ammonium (Table 1). Although flow appears to have influenced uptake rates for the large size fraction of epiphytes, this effect was not statistically significant for $U_{\mathrm{b}}$ and was slightly above the significance level for shear stress $\left(\rho_{\mathrm{Chl}}=\left[0.14 \times 10^{-10}\right] \tau_{\mathrm{R}}^{0.35}, 95 \%\right.$ CLs on slope $=0.05$ and $0.65, r=0.71, p=0.07$ ). Epiphytes consisting of small cells $(<0.35 \mu \mathrm{m})$ exhibited uptake rates for $\mathrm{NO}_{3}{ }^{-}$that were higher than those of the large size fraction (paired $t$-test, $\mathrm{p}<0.01$ ) and dependent on hydrodynamics (Table 2, Fig. 4).

Rates of ammonium uptake for microphytobenthos, determined for 7 of the $9 \mathrm{NH}_{4}{ }^{+}$experiments, were not dependent on hydrodynamic parameters. Rates of $\mathrm{NO}_{3}{ }^{-}$uptake were lower than those for ammonium and were also not dependent on water flow (Table 1, Fig. 4).

Although suspended within the water column, uptake rates for PON were statistically significantly dependent on bulk velocity and shear stress (Table 2 , Fig. 4). The amount of PON in the water column during $\mathrm{NH}_{4}{ }^{+}$experiments was also dependent on $U_{\mathrm{b}}$ $\left(\mathrm{mg} \mathrm{PON}=[0.91] U_{\mathrm{b}}^{0.36}, \mathrm{CLs}\right.$ on slope $=0.14$ and 0.58, $\mathrm{r}=0.83, \mathrm{p}<0.01$ ) (Fig. 5). Although rates of nitrate uptake for PON tended to increase with velocity, dependence of nitrate uptake on hydrodynamic para- meters was not statistically significant. The concentration of PON in the water column during $\mathrm{NO}_{3}{ }^{-}$experiments was within the same range as $\mathrm{NH}_{4}{ }^{+}$experiments and tended to increase over the range of velocity; however, it was not significantly dependent on $U_{\mathrm{b}}$ (Fig. 5).

\section{Component contributions to nitrogen uptake}

The total DIN removed from the water column ranged from 0.082 to $0.184 \mathrm{~g} \mathrm{NH}_{4}-\mathrm{N} \mathrm{h}^{-1}$ for the $\mathrm{NH}_{4}{ }^{+}$ experiments and from 0.029 to $0.067 \mathrm{~g} \mathrm{NO}_{3}-\mathrm{N} \mathrm{h}^{-1}$ for the $\mathrm{NO}_{3}{ }^{-}$experiments. Approximately $63.5 \pm 10.9$ (SD) $\%$ of the ammonium and $49.7 \pm 12.9(\mathrm{SD}) \%$ of the nitrate was traced into the tissues of seagrass leaves, epiphytes, PON, and microphytobenthos. Seagrass leaves contributed only $3.6 \pm 1.4$ (SD) \% and $3.1 \pm 0.7$ (SD) \% to the total combined uptake by the four components analyzed of ammonium and nitrate, respectively (Fig. 6). Epiphytes (small and large combined) represented an estimated $43.9 \pm 11.4(\mathrm{SD}) \%$ of the $\mathrm{NH}_{4}{ }^{+}$and $47.6 \pm 8.7(\mathrm{SD}) \%$ of the $\mathrm{NO}_{3}{ }^{-}$removed by all components. Approximately $47.3 \pm 12.0$ (SD) \% of the total $\mathrm{NH}_{4}{ }^{+}$and $40.5 \pm 10.6$ (SD) \% of the total $\mathrm{NO}_{3}{ }^{-}$ accounted for was attributed to uptake by phytoplankton (PON). Microphytobenthos removed an estimated $5.1 \pm 2.0$ (SD) \% and $8.8 \pm 6.4$ (SD) \% of the total ammonium and nitrate, respectively, removed by all components combined (Fig. 6).

To assess the effects of processing epiphytes and seagrass leaves on ${ }^{15} \mathrm{~N}$ loss, samples of seagrass leaves with attached epiphytes were analyzed without separating or rinsing. These samples were more enriched in ${ }^{15} \mathrm{~N}$ than the combined seagrass and epiphyte samples that had been separated and rinsed, which indicated that approximately $21.1 \pm 11.4(\mathrm{SD}) \%$ of the ammonium and $16.4 \pm 8.5$ (SD) \% of the nitrate removed from
Fig. 3. Thalassia testudinum. Uptake by the seagrass community as a whole represented as an uptake rate constant $(S)$ for ammonium and nitrate versus (A) bulk velocity and (B) Reynolds shear stress. $r$ and $\mathrm{p}$ values are given in Table 2
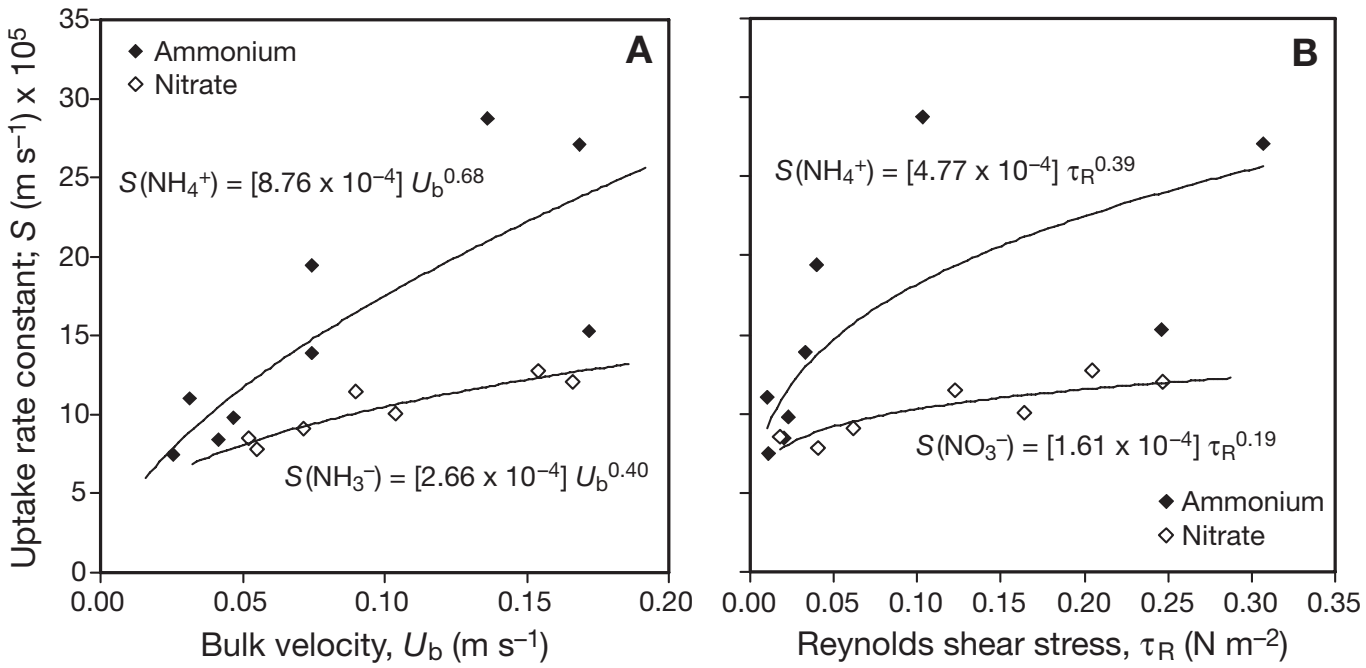

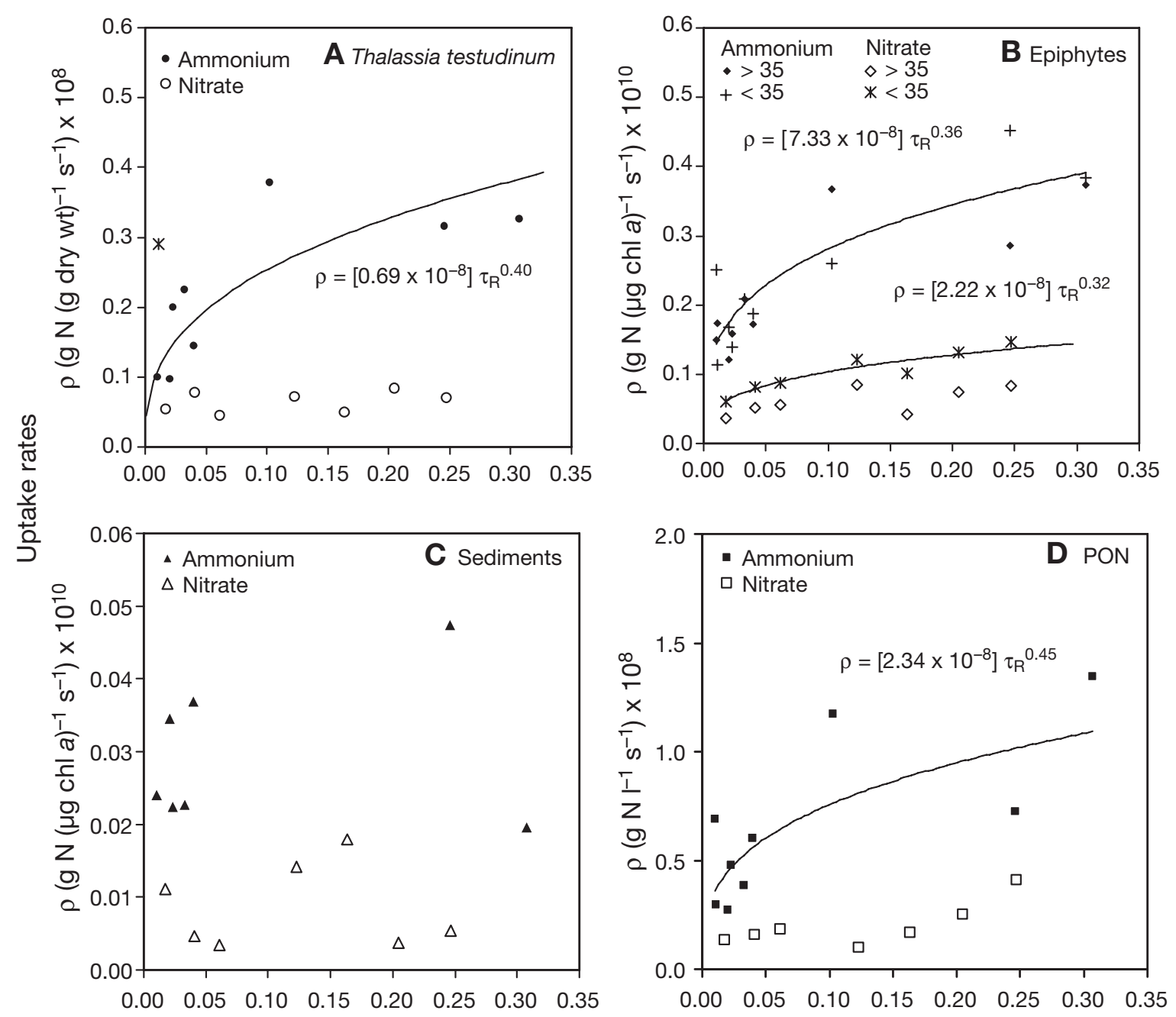

Reynolds shear stress, $\tau_{\mathrm{R}}\left(\mathrm{N} \mathrm{m}^{-2}\right)$

Fig. 4. Thalassia testudinum. Rates of ammonium and nitrate uptake for individual components of the seagrass community versus Reynolds shear stress $(\mathrm{R})$ at the top of the canopy. (A) For seagrass leaves, rates of $\mathrm{NH}_{4}{ }^{+}$uptake were significantly dependent on shear stress, and data were reanalyzed from Cornelisen \& Thomas (2004); $*$ : outlier. (B) Rates of $\mathrm{NH}_{4}{ }^{+}$uptake for both epiphyte size fractions were similarly dependent on $\tau_{\mathrm{R}}$ and were pooled for the regression shown. Nitrate uptake rates for epiphytes $<35 \mu \mathrm{m}$ were also dependent on $\tau_{\mathrm{R}}$. Uptake rates for epiphytes and (C) sediments were normalized to chl a concentration. (D) Rates of ammonium uptake by PON were dependent on $\tau_{\mathrm{R}}$. $\mathrm{r}$ and $\mathrm{p}$ values given in Table 2

the water column by the community was lost during sample processing. Therefore, an estimated $15 \%$ of the ammonium and $34 \%$ of the nitrate was removed by components or mechanisms unaccounted for in this study.

\section{DISCUSSION}

The interaction between water flow and bottom roughness controls rates of nutrient uptake for coral reef flats (e.g. Bilger \& Atkinson 1992, Hearn et al. 2001) and seagrass canopies (Thomas et al. 2000, Thomas \& Cornelisen 2003). In the present study, the relationships between uptake rate constants $(S)$ for ammonium and hydrodynamic parameters (bulk velocity and shear stress) were consistent with these results and indicate that rates of ammonium uptake for the seagrass community were limited by the rate at which ammonium was delivered to uptake surfaces within the benthos. Uptake rate constants for nitrate were also dependent on hydrodynamic parameters; however, the relationships were depressed relative to expectations, indicating that the community as a whole may have been in a transitional phase between physical and biological limitation (e.g. Sanford \& Crawford 2000). Nutrient flux to an uptake surface is dependent on both $S$ and the concentration gradient between 


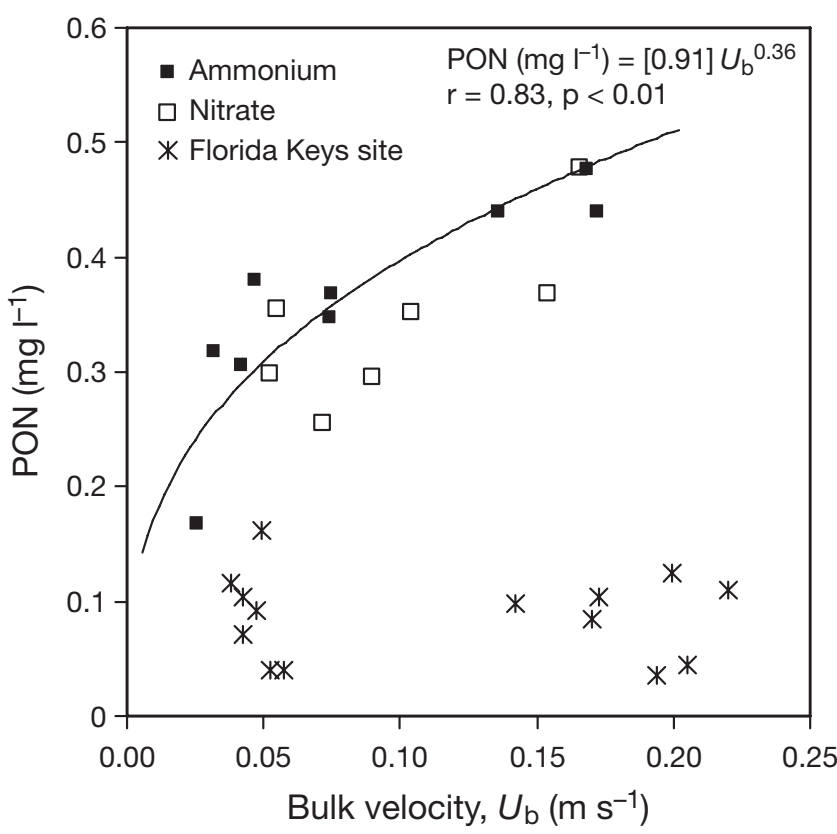

Fig. 5. The amount of PON in the water column versus bulk velocity $\left(U_{\mathrm{b}}\right)$. For ammonium uptake experiments the relationship between PON concentration and water velocity was significant. Also shown are estimates of PON in the water column during flume experiments conducted in a seagrass community in the Florida Keys that is regularly exposed to strong currents (Cornelisen 2003)

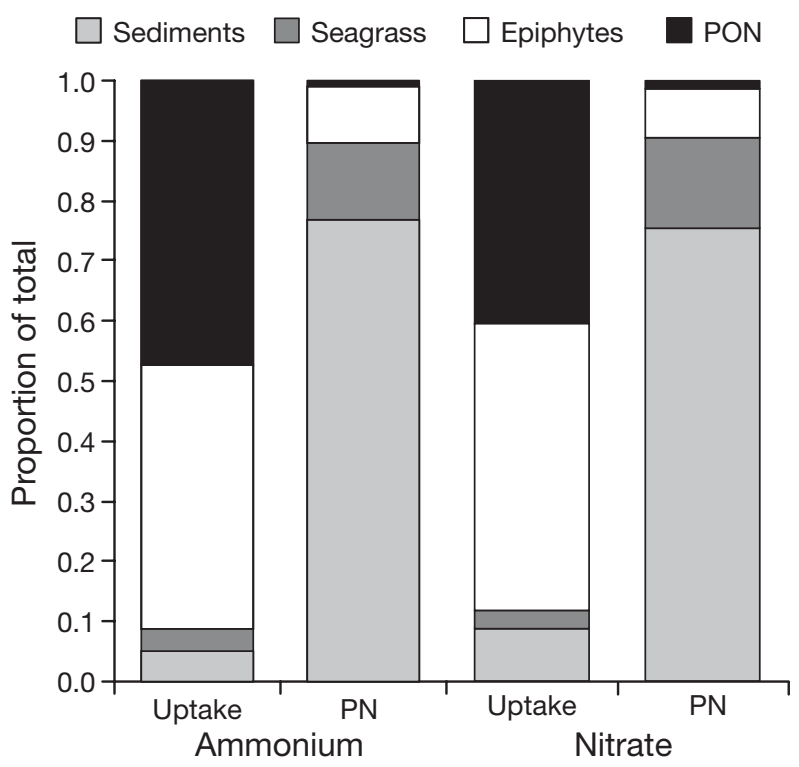

Fig. 6. Thalassia testudinum. The proportion of the total ${ }^{15} \mathrm{~N}$ labeled ammonium and ${ }^{15} \mathrm{~N}$-labeled nitrate recovered that was attributed to uptake by each component of the seagrass community. Also shown is the proportion that each component contributed to the total particulate nitrogen (PN) within the community. Particulate nitrogen is based on the total biomass of each component within the flume and the nitrogen concentration ( $\% \mathrm{~N})$ within each component the bulk fluid $\left(C_{\mathrm{b}}\right)$ and the uptake surface $\left(C_{\mathrm{W}}\right)$ (flux = $S\left(C_{\mathrm{b}}-C_{\mathrm{w}}\right)$. For nitrate, it is likely that the concentration gradient between uptake surfaces within the community and that of the water column was not maximal $\left(C_{\mathrm{w}}\right.$ increased), which reduced the relative impact of water flow on nitrate uptake by the community. In this case, a biological factor that affects uptake of nitrate, such as availability of nitrate reductase, may have been limiting rates of uptake for organisms within the community (Touchette \& Burkholder 2000).

The slope of the relationship between rates of ammonium uptake for seagrasses and epiphytes and hydrodynamic parameters was within the range of that expected if the assemblage was mass-transfer limited (uptake rate $\sim U_{\mathrm{b}}{ }^{0.75}, \tau^{0.40}$; Hearn et al. 2001). Furthermore, uptake rates for both size classes of epiphytes were similar and equally dependent on velocity and shear stress, providing further evidence that the rate of $\mathrm{NH}_{4}{ }^{+}$uptake by organisms within the canopy was a physically-driven process, rather than a process controlled by physiological differences among organisms. Thus, hydrodynamic characteristics of the flow have a similar effect on uptake of ammonium by the entire assemblage and some important individual components of the community.

Flow in vegetated canopies is more appropriately characterized using a mixing-layer analogy (Raupach et al. 1996, Ghisalberti \& Nepf 2002) rather than logarithmic law (see Stephan \& Gutknecht 2002). However, an important question remains to be answered: what is the most appropriate hydrodynamic parameter to link with nutrient transport processes in seagrass canopies? Our results suggest that estimates of Reynolds shear stress at the top of the canopy may be a good proxy for the hydrodynamic regime throughout the canopy and its effects on nutrient uptake by seagrass leaves and associated epiphytes. Despite the complexity of flow through seagrass canopies, estimates of bulk velocity $\left(U_{\mathrm{b}}\right)$ also correlated well with rates of ammonium uptake, which is likely due to the close relationship between $U_{\mathrm{b}}$ and shear at the top of the canopy (e.g. ln $\tau_{\mathrm{R}}=21.3 U_{\mathrm{b}}-5.0, \mathrm{r}^{2}=0.98$; Fig. 2). Several studies have modeled nutrient transport in complex habitats based on simple estimates of bulk velocity and a friction coefficient for the benthos (e.g. Baird \& Atkinson 1997, Thomas \& Atkinson 1997, Thomas et al. 2000).

Contrary to a non-flexible surface, friction imposed by a seagrass canopy on the water column is lessened by bending of the canopy as flow increases (Thomas et al. 2000). Bending of the canopy may aid transport to seagrass leaves and attached epiphytes by exposing more of the leaf surfaces within the region of enhanced shear. It is probable that ammonium uptake for the seagrass and epiphytes varies along the leaf surface with uptake being greatest within the top and lowest at 
the base of the canopy. Uptake rates were based on whole leaves and all of the attached epiphytes, thereby preventing an evaluation of the effect of canopy location on this parameter. However, ammonium uptake by microphytobenthos at the base of the canopy was not flow dependent. While this may be due to biological factors limiting uptake rates for this component, it could also be explained by significant flow attenuation by the canopy. Estimates of Reynolds shear stress within $1 \mathrm{~cm}$ of the sediment surface were an order of magnitude lower than those estimated at the top of the canopy (see Fig. 2). Furthermore, mean velocity near the sediment surface remained below $0.01 \mathrm{~m} \mathrm{~s}^{-1}$ over the range of bulk velocity ( 0.02 to $0.17 \mathrm{~m} \mathrm{~s}^{-1}$ ) imposed on the community during experiments.

The flow-dependent $\mathrm{NH}_{4}{ }^{+}$uptake by the PON fraction in the water column was unexpected. With the exception of large phytoplankton cells $(>60 \mu \mathrm{m})$ and chains, the effect of turbulence and shear on nutrient uptake by phytoplankton is expected to be minimal (Karp-Boss et al. 1996). Our ability to evaluate and interpret effects of shear on uptake by this component was limited, since the actual amount of PON in the water column was dependent on water velocity (see Fig. 5). In addition, the PON fraction was not normalized to chl a concentrations; therefore, we are unable to quantify the contribution of epiphytes and microphytobenthos versus sediment detritus to the increased PON in the water column. Nonetheless, uptake by the PON pool increased with the increase in PON concentration, which suggests that those organisms which actively remove dissolved forms of nitrogen, such as epiphytes and microphytobenthos, contributed to the resuspended organic matter. This result has important implications for the coupling of nutrient cycling and resuspension events in estuarine and nearshore systems. Ammonium concentrations in estuarine waters can become elevated during resuspension events (Cowan et al. 1996). A rapid increase in $\mathrm{NH}_{4}{ }^{+}$ uptake in the water column would be expected to accompany the elevated ammonium concentration, in part due to the increase in available $\mathrm{NH}_{4}{ }^{+}$, but also the resuspension of organisms into the water column that in turn remove ammonium at a higher rate per biomass than the benthic components. The effect of resuspension on uptake rates in the water column will be dependent on several site characteristics, including hydrodynamic regime, pore-water chemistry, shoot density and the composition of the epiphytic community (Koch 1999). For instance, resuspension of microphytobenthos or epiphytes and subsequent uptake would be minimal in an area regularly exposed to waves and strong tides, as demonstrated by data collected within channels of the Florida Keys, where currents can exceed $0.5 \mathrm{~m} \mathrm{~s}^{-1}$ (see Fig. 5) (Cornelisen 2003).
Rates of nitrate uptake were up to 4 times lower than those for ammonium, and with the exception of epiphytes water flow had no effect on uptake rates. Preferential uptake of ammonium over nitrate is commonly observed in benthic macrophytes and has been attributed to the added energy requirements associated with assimilating nitrate (Lee \& Dunton 1999, Touchette \& Burkholder 2000, Dudley et al. 2001). Ambient nitrate concentrations at our study site were low $\left(\sim 0.10 \mu \mathrm{mol} \mathrm{l}^{-1}\right)$, so it is possible that components in the seagrass community lacked the enzyme pool (e.g. nitrate reductase) to assimilate nitrate within the short time period that they were exposed to the elevated concentration in the flume. Rates of nitrate uptake for epiphytes $<35 \mu \mathrm{m}$ were higher than those for the larger size fraction, indicating that the small epiphytes may have been physiologically more capable of responding to increased nitrate concentrations. A greater surface area to volume ratio may have also enhanced uptake in the smaller size class (Hein et al. 1995). However, similar differences were not observed in the ammonium experiments, and the effects of cell size on uptake would presumably be less important for organisms lying within an epiphytic mat than those in the water column.

Epiphytes and phytoplankton were the primary sinks for the ammonium and nitrate added to the water column, which is consistent with enhanced productivity of these components under nutrient enrichment (Tomasko \& Lapointe 1991, Short et al. 1995). Epiphytes and phytoplankton depend on water-column nutrients and are in opportunistic locations for maximizing nutrient concentration adjacent to uptake surfaces. Lower uptake for seagrass leaves and microphytobenthos compared to epiphytes and phytoplankton is likely due to a combination of factors, including inhibitory effects of epiphyte cover on uptake by seagrass leaves (Cornelisen \& Thomas 2004) and depleted nutrient concentrations within the lower region of the canopy, which in turn is due to the dynamics of fluid flow through vegetated canopies and the interception of nutrients by overlying components. For example, with increasing flow and subsequent bending of the canopy, water at the base of the canopy may become nutrient depleted. Vertical transport of momentum into the canopy, perhaps enhanced by monami (synchronous waving of seagrass plants), may play an important role in replenishing the base of the canopy with water-column nutrients (Ghisalberti \& Nepf 2002).

Uptake rates for seagrass leaves in our study were up to 10 times lower than those estimated in previous studies involving Thalassia testudinum (Lee \& Dunton 1999) and Thalassia hemprichii (Stapel et al. 1996). Uptake by seagrass leaves met up to half of the plants' required nitrogen in these previous studies. If we 
assume similar nitrogen demands for the seagrass at our study site, then the roots are likely supplying the majority of required nitrogen. Alternative explanations include more effective internal recycling of nitrogen within the plants at our study site compared to those of the other sites, or the possibility that uptake rates for the seagrass leaves were underestimated in our study due to the short duration of experiments. Epiphytes transfer nutrients to seagrass leaves over time (McRoy \& Goering 1974), and experiments lasting $24 \mathrm{~h}$ estimated that uptake by Ruppia megacarpa leaves covered uniformly with epiphytic diatoms, contributed up to $30 \%$ of the ammonium and $40 \%$ of the nitrate recovered in R. megacarpa communities (Dudley et al. 2001). It is therefore possible that a portion of the ammonium and nitrate washed away from the epiphyte-leaf assemblage during our sample processing, or perhaps nitrogen excreted from the epiphytes themselves, would have been assimilated by the leaves over a longer time period.

The 2 major sinks for the added DIN (epiphytes and PON) contributed the least to the total particulate nitrogen (PN) within the seagrass community (Fig. 6). Conversely, the components that contributed the least to uptake from the water column (seagrass leaves and sediments) contained the majority of the particulate nitrogen. The contribution of individual components to the uptake of DIN from the water column as well as their contribution to the total particulate nitrogen pool is expected to vary seasonally and spatially due to changes in productivity levels among components. Nonetheless, our results emphasize the importance of epiphytes and phytoplankton in uptake of watercolumn DIN over the short term, and suggest that seagrasses and sediments play a more integral role in the long-term cycling and retention of nitrogen within the system. The large amount of PN within the sediments suggests that a major source of nitrogen for the seagrass may be mineralized nitrogen from the breakdown of detritus at the surface of the sediments. This is supported by Evrard et al. (2005), who demonstrated uptake of nitrogen mineralized from sediment phytodetritus by seagrass roots and subsequent translocation to their leaves. The canopy's ability to attenuate flow and trap particles may therefore play a crucial role in maintaining nitrogen supply to seagrasses in oligotrophic environments (Stapel et al. 2001, Evrard et al. 2005). Based on our findings, this would also apply when epiphytes and phytoplankton are abundant and dominate uptake of water-column nutrients.

We were unable to account for approximately $15 \%$ of the ammonium and $34 \%$ of the nitrate removed from the water column. As was the case for epiphytes, a portion of this DIN may have been lost during filtering and rinsing of PON samples (Laws 1984). Short shoots at the base of seagrass plants were not included in the analysis and may have accounted for some uptake. It is also possible that DIN was transported deeper than $1 \mathrm{~cm}$ into the sediments. Other contributing mechanisms not accounted for include the conversion of inorganic to organic forms of nitrogen (DON) by epiphytes and phytoplankton, and nitrification-denitrification processes (Boynton et al. 1995, Dudley et al. 2001). The amount of ${ }^{15} \mathrm{NO}_{3}{ }^{-}$not recovered was twice as high as the amount for ${ }^{15} \mathrm{NH}_{4}{ }^{+}$, suggesting loss of ${ }^{15} \mathrm{~N}$ as $\mathrm{N}_{2}$ gas during denitrification in the sediments or within the epiphyte assemblage (Kaspar 1983). Rates of denitrification increase with enhanced enrichment of $\mathrm{NO}_{3}{ }^{-}$ despite the presence of $\mathrm{O}_{2}$ (Kana et al. 1998).

\section{CONCLUSIONS}

The deployment of a field flume and application of isotope labels in natural seagrass beds allowed for the isolation of the effects of hydrodynamic regime on rates of ammonium and nitrate uptake for the major photosynthetic components of a seagrass community. Results demonstrated that mass-transfer relationships between hydrodynamic parameters and nutrient uptake can apply at both the level of the community and individual components within the community. In addition, the relative importance of water flow in controlling uptake rates will depend on the form of dissolved nitrogen being assimilated. Epiphytes and phytoplankton were the dominant sinks for ammonium and nitrate over the short term; however, the large amount of particulate nitrogen within seagrasses and surface sediments suggests that these components may play a more important role in the removal of DIN from the water column over the long term through the trapping and retention of organic particles and detritus. Seagrass communities exist in physically dynamic environments that are exposed to a range of hydrodynamic conditions. The interactions between biological and physical processes in seagrass communities and the effects of these interactions on nutrient cycling must be addressed to determine the fate of water-column nutrients. Future research involving application of isotope labels in field-based studies will provide further insight into the mechanisms controlling nutrient transport in nearshore and estuarine systems.

Acknowledgements. We thank the numerous individuals that contributed to fieldwork, including A. Bass, N. Craig, M. Driscoll, S. Kinane, H. Porter, K. Sharpe, and K. Wall. Insightful discussions with C. Hearn aided in data interpretation. Assistance with epiphyte identification by M. Hall is greatly appreciated. We also thank Iso-Analytical Ltd and K. Fanning's lab and staff for assistance with sample analysis, as well as the staff at Fort Desoto Park. Two anonymous reviews 
greatly improved the manuscript. This research represents a portion of C.D. Cornelisen's doctoral research at University of South Florida and was funded by a National Science Foundation PECASE award to F.I.M. Thomas (OCE-9996361).

\section{LITERATURE CITED}

Baird M, Atkinson MJ (1997) Measurement and prediction of mass transfer to coral reefs. Limnol Oceanogr 42: 1685-1693

Baird ME, Roughan M, Brander RW, Middleton JH, Nippard GJ (2004) Mass-transfer-limited nitrate uptake on a coral reef flat, Warraber Island, Torres Strait, Australia. Coral Reefs 23:386-396

Bilger RW, Atkinson MJ (1992) Anomalous mass transfer of phosphate on coral reef flats. Limnol Oceanogr 37 : 261-272

Boynton WR, Garber JH, Summers R, Kemp WM (1995) Inputs, transformations, and transport of nitrogen and phosphorus in Chesapeake Bay and selected tributaries. Estuaries 18:285-314

Cornelisen CD (2003) Nutrient uptake by seagrass communities and associated organisms: impact of hydrodynamic regime quantified through field measurements and use of an isotope label. PhD dissertation, University of South Florida, Tampa, FL

Cornelisen CD, Thomas FIM (2002) Ammonium uptake by seagrass epiphytes: isolation of the effects of water velocity using an isotope label. Limnol Oceanogr 47:1223-1229

Cornelisen CD, Thomas FIM (2004) Ammonium and nitrate uptake by leaves of the seagrass Thalassia testudinum: isolation of the effects of hydrodynamic regime and epiphyte cover on uptake rates. J Mar Syst 49:177-194

Cowan JLW, Pennock JR, Boynton WR (1996) Seasonal and interannual patterns of sediment-water nutrient and oxygen fluxes in Mobile Bay, Alabama (USA): regulating factors and ecological significance. Mar Ecol Prog Ser 141: 229-245

Dickson ML, Wheeler PA (1995) Nitrate uptake rates in a coastal upwelling regime: a comparison of PN-specific, absolute, and chl a-specific rates. Limnol Oceanogr 40: 533-543

Dudley BJ, Gahnström AME, Walker DI (2001) The role of benthic vegetation as a sink for elevated inputs of ammonium and nitrate in a mesotrophic estuary. Mar Ecol Prog Ser 219:99-107

Dugdale RC, Goering JJ (1967) Uptake of new and regenerated forms of nitrogen in primary productivity. Limnol Oceanogr 12:196-206

Eckman JE (1987) The role of hydrodynamics in recruitment, growth, and survival of Argopecten irradians (L.) and Anomia simplex (D'Orbigny) within eelgrass meadows. J Exp Mar Biol Ecol 106:165-191

Evrard V, Kiswara W, Bouma TJ, Middelburg JJ (2005) Nutrient dynamics of seagrass ecosystems: ${ }^{15} \mathrm{~N}$ evidence for the importance of particulate organic matter and root systems. Mar Ecol Prog Ser 295:49-55.

Fonseca MS, Kenworthy J (1987) Effects of current on photosynthesis and distribution of seagrass. Aquat Bot 27:59-78

Ghisalberti M, Nepf HM (2002) Mixing layers and coherent structures in vegetated aquatic flows. J Geophys Res 107: $1-11$

Hansen JW, Pedersen AU, Berntsen J, Ronbog IS, Hansen LS, Lomstein BA (2000) Photosynthesis, respiration, and nitrogen uptake by different compartments of a Zostera marina community. Aquat Bot 66:281-295
Hearn CJ, Atkinson MJ, Falter JL (2001) A physical derivation of nutrient-uptake rates in coral reefs: effects of roughness and waves. Coral Reefs 20:347-356

Hein M, Pedersen MF, Sand-Jensen K (1995) Size-dependent nitrogen uptake in micro- and macroalgae. Mar Ecol Prog Ser 118, 247-253.

Iizumi H, Hattori A (1982) Growth and organic production of eelgrass (Zostera Marina L.) in temperate waters of the Pacific coast of Japan. III. The kinetics of nitrogen uptake. Aquat Bot 12:245-256

Kana TM, Sullivan MB, Cornwell JC, Groszkowski K (1998) Denitrification in estuarine sediments determined by membrane inlet mass spectrometry. Limnol Oceanogr 43:334-339

Karp-Boss L, Boss E, Jumars PA (1996) Nutrient fluxes to planktonic osmotrophs in the presence of fluid motion. Oceanogr Mar Biol Annu Rev 34:71-107

Kaspar HF (1983) Denitrification, nitrate reduction to ammonium, and inorganic nitrogen pools in intertidal sediments. Mar Biol 74:133-139

Koch E (1999) Sediment resuspension in a shallow Thalassia testudinum banks ex König bed. Aquat Bot 65: $269-280$

Laws E (1984) Isotope dilution models and the mystery of the vanishing ${ }^{15}$ N. Limnol Oceanogr 29:379-386

Lee KS, Dunton KH (1999) Inorganic nitrogen acquisition in the seagrass Thalassia testudinum: development of a whole-plant budget. Limnol Oceanogr 44:1204-1215

Lorenzen CJ (1967) Determination of chlorophyll and phaeopigment: spectrophotometric equations. Limnol Oceanogr 12:343-346.

McRoy CP, Goering JJ (1974) Nutrient transfer between the seagrass Zostera marina and its epiphytes. Nature 248: 173-174

Moncreiff CA, Sullivan MJ, Daehnick AE (1992) Primary production dynamics in seagrass beds of Mississippi Sound: the contributions of seagrass, epiphytic algae, sand microflora, and phytoplankton. Mar Ecol Prog Ser 87: 161-171

Raupach MR, Finnigan JJ, Brunet Y (1996) Coherent eddies and turbulence in vegetation canopies: the mixing layer analogy. Boundary-Layer Meteorol 78:351-382

Sanford LP, Crawford SM (2000) Mass transfer versus kinetic control of uptake across solid-water boundaries. Limnol Oceanogr 45:1180-1186

Short FT, McRoy CP (1984) Nitrogen uptake by leaves and roots of the seagrass Zostera marina L. Bot Mar 27: $547-555$

Short FT, Short CA (1984) The seagrass filter: purification of coastal water. In: Kennedy VS (ed) The estuary as a filter. Academic Press, Orlando, FL, p 395-413

Short FT, Burdick DM, Kaldy JE (1995) Mesocosm experiments quantify the effects of eutrophication on eelgrass, Zostera marina. Limnol Oceanogr 40:740-749

Sokal RR, Rohlf FJ (1995) Biometry, 3rd edn. Freeman, New York

Stapel J, Aarts TL, van Duynhoven BHM, de Groot JD, van den Hoogen PHW, Hemminga MA (1996) Nutrient uptake by leaves and roots of the seagrass Thalassia hemprichii in the Spermonde Archipelago, Indonesia. Mar Ecol Prog Ser 134:195-206

Stapel J, Hemminga MA, Bogert CG, Maas YEM (2001) Nitrogen ${ }^{15} \mathrm{~N}$ retention in small Thalassia hemprichii seagrass plots in an offshore meadow in South Sulawesi, Indonesia. Limnol Oceanogr 46:24-37

Stephan U, Gutknecht D (2002) Hydraulic resistance of submerged flexible vegetation. J Hydrol 269:27-43 
Thomas FIM, Atkinson MJ (1997) Ammonium uptake by coral reefs: effects of water velocity and surface roughness on mass transfer. Limnol Oceanogr 42:81-88

Thomas FIM, Cornelisen CD (2003) Ammonium uptake by seagrass communities: effects of oscillatory versus unidirectional flow. Mar Ecol Prog Ser 247:51-57

Thomas FIM, Cornelisen CD, Zande JM (2000) Effects of water velocity and canopy morphology on ammonium uptake by seagrass communities. Ecology 81:2704-2713

Tomasko DA, Lapointe BE (1991) Productivity and biomass of

Editorial responsibility: Kenneth L. Heck Jr (Contributing Editor), Dauphin Island, Alabama, USA
Thalassia testudinum as related to water column nutrient availability and epiphyte levels: field observations and experimental studies. Mar Ecol Prog Ser 75:9-17

Touchette BW, Burkholder JM (2000) Review of nitrogen and phosphorus metabolism in seagrasses. J Exp Mar Biol Ecol 250:133-167

Wheeler PA, Glibert PM, McCarthy JJ (1982) Ammonium uptake and incorporation by Chesapeake Bay phytoplankton: short term uptake kinetics. Limnol Oceanogr 27:1113-1128

Submitted: June 21, 2005; Accepted: November 29, 2005 Proofs received from author(s): March 9, 2006 